матеріально-технічне забезпечення здійснюється з урахуванням того, що іншомовна педагогічна освіта $\epsilon$ своєрідною проекцією майбутньої професійної діяльності, спрямованої на навчально-виховний процес у певному навчальному закладі і має метою підготовку вітчизняної еліти, креативних особистостей високого рівня освіченості, інтелігентності, моралі і духовності, що забезпечується впровадженням української національної ідеї у процес іншомовної освіти (у зв'язку з викликами глобалізаційних перспектив), тому володіння іноземною мовою стає життєво необхідним чинником.

Отже, виявлена соціально-економічна, лінгвосоціокультурологічна та педагогічна значущість проблеми підготовки сучасного педагога, недостатній рівень іï наукової розроблення та невизначеність шляхів розв'язання виявлених суперечностей системи професійного навчання студентів в умовах університетської підготовки, актуальність, теоретичне й практичне значення ефективної іншомовної освіти майбутніх педагогів і водночас відсутність цілісного дослідження проблеми іншомовної освіти майбутніх педагогів в умовах вищої освіти (на базі вивчення іноземних мов за професійним спрямуванням) потребують подальшого комплексного дослідження.

Проте, зважаючи на дискусійність та різноплановість підходів щодо розгляду іншомовної освіти, зокрема, в умовах вищої школи, наш подальший науковопрактичний пошук полягатиме в розробленні педагогічної концепції іншомовної освіти й алгоритму іiі дії в умовах університетської підготовки майбутніх педагогів; емпіричне підтвердження ефективності іiі технологічного забезпечення, виявлення основних тенденцій розвитку іншомовної освіти під впливом глобалізаційних перспектив.

\title{
Література
}

1. Педагогічна Конституція Європи [Електронний ресурс].- Режим доступу : http://www.arpue.org/index.php/ru/hlavnaia/104-pedagogicheskaya-konstitutsiya-evropy/141pedahohichna-konstytutsiia-yevropy-1 2. Про Концепцію державної мовної політики / Указ Президента України № 161/2010 [Електронний ресурс].- Режим доступу : http://www.president.gov.ua/documents/10486.html 3. Махінов В.М. Становлення мовної особистості в історії розвитку європейського соціокультурного освітнього простору : [монографія] / В. М. Махінов ; Нац. пед. ун-т ім. М. П. Драгоманова. - Київ : Вид-во НПУ імені М. П. Драгоманова, 2012. - 427 с. 4. Петько Л. В. Впровадження української національної ідеї в процес іншомовної освіти майбутніх педагогів / Л. В. Петько // Вища освіта України : теоретичний та науково-методичний часопис / засн. Інститут вищої освіти АПН України; голов. ред. В. П. Андрущенко. - Київ : Педагогічна преса, 2013. №2. - С. 68-74.

\section{ДИДАКТИЧНА АДАПТАЦІЯ ФОРМ, МЕТОДІВ, ПРИЙОМІВ І ЗАСОБІВ САМОСТІЙНОЇ ПІЗНАВАЛЬНОЇ ДІЯЛЬНОСТІ В ПАРАДИГМІ УЧЕНЬ СТАРШОЇ ШКОЛИ - СТУДЕНТ ВИЩОГО НАВЧАЛЬНОГО ЗАКЛАДУ}

Полякова В. Я. Дидактична адаптація форм, методів, прийомів і засобів самостійної пізнавальної діяльності в парадигмі учень старшої школи - студент вищого навчального закладу.

У статті на грунті здійсненого психолого-педагогічного аналізу розглянуто дидактичну адаптацію форм, методів, прийомів і засобів самостійної пізнавальної діяльності в парадигмі учень старшої школи - студент вищого навчального закладу як одну з дидактичних умов організації самостійної навчальної діяльності учнів старшої школи. 
Ключові слова: дидактична адаптація, форми, методи, прийоми, засоби самостійної пізнавальної діяльності, самостійна навчальна діяльність, організація самостійної навчальної діяльності.

Полякова В. Я. Дидактическая адаптация форм, методов, приемов, средств познавательной деятельности в парадигме ученик старшей школы - студент высшего учебного заведения.

В статье на основе проведенного психолого-педагогического анализа рассмотрена дидактическая адаптация форм, методов, приёмов, средств самостоятельной познавательной деятельности в парадигме ученик старшей школы - студент высшего учебного заведения как одного из дидактических условий организации самостоятельной учебной деятельности учащихся старшей школы.

Ключевые слова: дидактическая адаптация, формы, методы, приёмы, средства самостоятельной учебной деятельности, самостоятельная учебная деятельность, организация самостоятельной учебной деятельности.

Polyakova V. Y. Didactic adaptation of forms, methods, techniques, methods of independent cognitive activity in the paradigm of high school student - a student of higher academic institutions.

Didactic adaptation of forms, methods, techniques, methods of independent cognitive activity in the paradigm of high school student - a student of higher academic institutions as one of the conditions for the organization of teaching self-learning activities of students of high school is considered on the basis of psycho-pedagogical analysis.

Key words: didactic adaptation, forms, methods, techniques, methods of self-educational activities, self- educational activity, the organization of independent educational activities.

Реалізація неперервної освіти в Україні стає об’єктивною потребою й пріоритетним напрямом державної політики в галузі освіти. На сучасному етапі динамічного розвитку системи неперервної освіти особливу увагу слід приділити подоланню розрізненості й неузгодженості між іiі освітніми ланками, налагодженню наступності між ними. Законами України «Про освіту» (1996 р.), «Про загальну середню освіту» (1999 р.), «Про вищу освіту» (2002 р.), новим «Державним стандартом базової і повної загальної освіти» (2011р.), «Положенням про загальноосвітній навчальний заклад» (2010р.), «Концепцією профільного навчання в старшій школі» (2009р.) та іншими важливими документами, визначаються структурно-змістові і процесуальні перетворення, спрямовані на забезпечення цього провідного напряму.

Розв'язання проблеми наступності в загальнодидактичному аспекті здійснювалося в роботах А. Алексюка, Б. Ананьєва, С. Годника, С. Гончаренка, К. Делікатного, Г. Запорожець, І. Зязюна, А. Киверялга, В. Мадзігона, О. Мороза, Н. Тализіної та ін. Питанням наступності у професійній підготовці фахівців були присвячені дисертаційні дослідження Ю. Кустова, А. Литвина, О. Пінаєвої, наукові праці М. Безрядіна, I. Борисенка, О. Брехова, В. Манько, Г. Щевелевої, Я. Цехмістера. Значення наступності між загальноосвітньою школою i вищим педагогічним навчальним закладом в професійному становлені студентів-педагогів розкрито в дисертаціях С. Козаченко, О. Малихіна, Г. Удовиченко.

Концепцією профільного навчання в старшій школі визначено наступність i неперервність серед освітніх принципів, на яких грунтується профільне навчання. Принцип наступності в безперервній освіті передбачає досягнення наскрізних для всіх рівнів цілей, зокрема, формування особистості молодої людини та якісну підготовку 
майбутнього фахівця на основі узгодженості концептуальних підходів під час визначення вимог до рівня і змісту його теоретичної та практичної підготовки. Водночас принцип наступності сприяє усуненню дидактичних суперечностей між специфічними особливостями загальноосвітньої та вищої шкіл.

Одним із пріоритетів оновлення змісту освіти $є$ забезпечення наступності навчального змісту і вимог щодо його засвоєння між загальноосвітньою підготовкою та вимогами вищої освіти. У компонентах дидактичних систем загальноосвітньої та вищої школи мають місце суперечності, пов'язані 3 особливостями діяльності суб'єктів навчання, зокрема, форм, методів навчання i контролю за його результатами. Навчально-виховний процес у загальноосвітній школі організовується за класноурочною системою, а у вищих навчальних закладах - за кредитно-модульною системою і відповідними організаційними формами навчання.

Аналіз психолого-педагогічних джерел, проведені спостереження дозволили 3'ясувати, що суттєві вияви дидактичної дезадаптації студентів першого курсу зумовлені специфічною організацією навчального процесу у вищому навчальному закладі. Засоби дидактичної адаптації студентів повинні розв'язувати об'єктивну суперечність між загальними вимогами неперервності характеру освіти і дискретністю, неузгодженістю і відмінностями форм навчання в загальноосвітній школі і вищому навчальному закладі. Названа суперечність може бути усунена визначенням i дотриманням наступності форм, методів, прийомів і засобів навчання в загальноосвітній школі і ВНЗ. У своєму дослідженні ми виходили з розуміння дидактичної категорії «форма навчання» як родової узагальнюючої назви, що об'єднує в собі поняття «система навчання», «форма організації навчання», «форма організації самостійної пізнавальної діяльності». Названі форми характеризуються певною ієрархією - форми організації самостійної пізнавальної діяльності згуртовані відповідно для виконання конкретного завдання, утворюють форми організації навчання, інтегрування цих форм створює системи навчання.

Цілком очевидним є зв’ язок проблеми з практичними завданнями як середньої, так і вищої школи. IIÏ успішне розв'язання сприятиме оптимальній адаптації випускника школи до специфіки навчання у вищому навчальному закладі, формуванню вмінь i навичок навчатися протягом усього життя.

Mema cmammi: розкрити проблему дидактичної адаптації форм, методів, прийомів і засобів самостійної пізнавальної діяльності у парадигмі учень старшої школи - студент вищого навчального закладу як одну 3 дидактичних умов організації самостійної навчальної діяльності учнів старшої школи.

Задля забезпечення наступності в парадигмі: учень старшої школи - студент вищого навчального закладу вважаємо необхідним здійснювати дидактичну адаптацію форм, методів, прийомів і засобів самостійної пізнавальної діяльності.

Навчальна діяльність учня старшої школи істотно відрізняється за своїм характером і змістом від навчальної діяльності студента у вищому навчальному закладі: в останнього значно збільшується обсяг знань, розширюється спектр виучуваних дисциплін, що вимагають для їх успішного засвоєння розширення кругозору в профільній сфері. Психологічна атмосфера у вищому навчальному закладі також значно відрізняється від шкільної за рахунок високої мотивації студентів на навчання за обраною спеціальністю й порівняно високого рівня самостійності студентів у навчальному процесі. При цьому такі особистісні якості студента, як низька самооцінка, відсутність комунікативних навичок, невміння будувати стосунки в колективі, брати на себе відповідальність можуть заважати його успішній реалізації в освітньому просторі 
ВНЗ. У цьому зв'язку школярів у старших класах необхідно цілеспрямовано готувати до вишівського навчального середовища.

Узагальнення окремих аспектів адаптаційних процесів студентів до навчання у вищих навчальних закладах здійснюється в роботах Д. Андреєвої, Л. Гришанова, В. Смельянова, Г. Левківської, О. Ланцової, І. Ляхової, Н. Московцева, А. Новодворкіс, К. Назарової, Н. Петрової, Л. Пономарьової, В. Сорочинської, О. Суіменко, О. Учителя, В. Чайки, В. Цуркана, Л. Яковенко.

Дослідженню розвитку форм навчання присвячені роботи А. Алексюка,

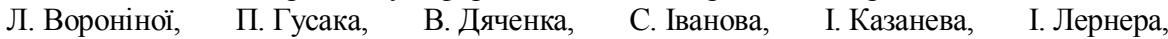
Ю. Мальованого, М. Махмутова, А. Нісімчука, І. Огородникова, О. Падалки, В. Петренко, В. Римаренка, Г. Саранцева, І. Смолюка, I. Чередова, О. Шпака та ін.

Структура навчального процесу в загальноосвітніх навчальних закладах дозволяє учням уже в старшій школі ознайомитися зі специфічними організаційними формами навчання у вищих навчальних закладах, такими, як лекції, семінарські заняття, дискусії, конференції, консультації, написання та захист науково-дослідницьких робіт, широким спектром методів навчання, прийомами та засобами, що сприяють формуванню та розвитку вмінь і навичок самостійної навчальної діяльності.

У загальноосвітньому навчальному закладі широко використовуються уроки-лекції як одна із організаційних форм навчання. Їх основою $є$ системне усне викладення вчителем навчального матеріалу протягом уроку (чи пари уроків), головний зміст якого становлять аналіз та узагальнення фактів, а провідними прийомами - пояснення та розмірковування.

Як зазначає В. Ягупов, «сучасна дидактика й особливості соціальної діяльності вимагають урізноманітнення класичної лекції. Задля цього використовуються певні прийоми і засоби активізації названої форми: лекція-бесіда, під час якої можуть використовуватися проблемні запитання, лекція - аналіз конкретної ситуації, лекція 3 використанням техніки зворотного зв'язку, лекція-консультація, лекція-пресконференція, лекція із заздалегідь запланованими помилками тощо» [3, с. 370].

Ураховуючи власний педагогічний досвід, у старшій школі активно застосовуємо інформаційно-комунікаційні технології, зокрема, лекції-презентації, лекції з виходом в Інтернет-простір тощо.

Слід зазначити, що під час проведення лекції в учнів формуються навички самостійного опрацювання почутого, побаченого. Ефективність лекції полягає також у тому, щоб в учнів сформувався інтерес до інформації, яка викладалася вчителем; виникло бажання якісно виконати домашнє завдання; набувають розвитку вміння учнів самостійно робити висновки, вносити пропозиції.

Під час засвоєння навчального матеріалу, який доступний для самостійного опрацювання, доцільно проводити уроки-семінари. Урок-семінар - це також одна із організаційних форм навчання, під час якої учні обговорюють та аналізують тему, питання, проблему, виявляють причинно-наслідкові зв'язки, віднаходять шляхи їх оптимального розв'язання, відповідають на запитання й дискутують. В. Ягупов стверджує, що «семінар - це творче поєднання позитивних властивостей бесіди й дискусії, але на більш високому методичному, науковому й теоретичному рівнях, що передбачає відповідну підготовленість суб'єктів учіння» [3, с. 335].

Ефективність семінару залежить від попередньої роботи педагога (організаційнотехнічний, теоретичний і методичний напрями якої найбільш оптимальні) й учнів, їх активної і творчої взаємодії.

Важливою $є$ самостійна навчальна діяльність учнів під час підготовки та проведення уроку-семінару. Роль учителя із традиційної змінюється на посередницьку, 
консультативну. Головним стає колективне знання класу, допомога у з'ясуванні сутності окремих питань, обговорення підготовлених самостійно повідомлень, виступів, інформацій тощо. У цьому випадку вчитель $є$ організатором начальної діяльності учнів, їхньої співпраці й одночасно партнером, старшим товаришем і фасалітатором.

Власна педагогічна практика дозволяє дійти висновку, що у старших класах ефективними $є$ уроки-дискусії. Слово «дискусія» латинського походження, що означає «міркую», «суперечу». Дискусія - одна з форм урочної роботи з учнями, яка допомагає розвивати їхню самостійність, логічне мислення, соціальну та моральну зрілість; формувати погляди та переконання особистості.

«Сутність дискусії, - на думку Ч. Купісевича, - полягає в обміні думками на певну тему між учителями й учнями або тільки між учнями. Ці думки можуть бути як власними, так і спиратися на погляди інших людей. Ефективність дискусії полягає в розмаїтті думок, бажанні відшукати найбільш оптимальний варіант розв'язання дидактичної проблеми, активній позиції в ній учасників» [2, с. 142].

Під час дискусії з'являються можливості впливу на інтелектуальну та емоційну сфери особистості учня; збудження його зацікавленості в пошуку істини. Окрім цього, у процесі дискусії створюються умови для реалізації демократичних засад навчання. На думку багатьох педагогів, учіння в дискусії сприяє розвитку критики та самокритики, культури мови та логічного мислення, навчає вмінню опонувати та перевіряти правильність своїх поглядів і переконань.

У процесі дискусії учні обговорюють не тільки запропоновані вчителем питання, а й ті, які виникли під час підготовки до неї. Крім того, учні набувають умінь і навичок самостійно працювати з різними джерелами інформації; оволодівають методами аналізу та синтезу; формують уміння узагальнювати, робити висновки та вносити пропозиції. У процесі дискусії, тобто зіткнення різних поглядів і думок, знання учнів уточнюються, поглиблюються, коригуються; вони вчаться аргументовано захищати власні думки, переконання, ідеї. У цьому аспекті вчителі-практики розглядать дискусію як один із засобів перетворення знань у переконання.

Учнівська конференція - це важлива організаційна форма навчання, що сприяє формуванню знань, умінь i навичок учнів, їх закріпленню та вдосконаленню, поглибленню й систематизації; це комплексна форма узагальнення результатів самостійної пізнавальної діяльності учнів під керівництвом учителя, що здійснюється завдяки спільним зусиллям учителя й учнів. Метою конференції $\epsilon$ поглиблення, зміцнення та розширення діапазону знань учнів; формування позитивного ставлення до самостійного набуття ними знань; розвиток і саморозвиток творчих здібностей учнів, їх активності; створення передумов самовиховання, самовдосконалення, самовизначення учнів.

Практика роботи загальноосвітніх навчальних закладів підтверджує, що доцільно проводити конференції $з$ таких тем, які б дозволили використовувати знання учнів 3 кількох навчальних предметів або підводили підсумки вивченого розділу. При цьому якість конференції підвищується завдяки об'єднанню зусиль учителів-предметників у ії підготовці та проведенні.

Дуже важливим, на наш погляд, є дидактичний аспект адаптації самого випускника загальноосвітнього навчального закладу до навчання у вищому навчальному закладі. Принцип наступності може бути дієвим і важливим засобом усунення невідповідності між загальноосвітнім характером підготовки в середній школі й спеціальними завданнями вищої. Крім того, дидактична адаптація самих студентів першого курсу пов'язана 3 подоланням стереотипів навчання в школі за класно-урочною системою і пристосуванням до нових вимог навчання у ВНЗ - за кредитно-модульною системою. 
Отже, дидактичну адаптацію студента-першокурсника до навчально-виховного процесу у вищому навчальному закладі можна розуміти як рівновагу між асиміляцією, тобто прийняттям нових змінених умов навчання до наявного навчального досвіду вчорашнього школяра, та акомодацією, тобто пристосуванням цього досвіду до навчально-виховного процесу в закладах вищої освіти.

Дидактична адаптація студента-першокурсника є складним динамічним процесом, який зумовлюється взаємним впливом зовнішніх та внутрішніх складників. Наступність дидактичних систем загальної середньої та вищої освіти утворює зовнішній складник. До внутрішнього складника слід віднести особистісну мотиваційну сферу і рівень інтелектуального розвитку студента. При цьому інтелект можна вважати змістовим ядром дидактичної адаптації студента-першокурсника.

Дидактична адаптація перебігає 3 різною інтенсивністю залежно від низки чинників.

Дидактична адаптація студента-першокурсника

\begin{tabular}{|c|c|}
\hline \multicolumn{2}{|c|}{ Зовнішній складник } \\
\hline \multicolumn{2}{|c|}{ Дидактична } \\
$\begin{array}{c}\text { система середньої } \\
\text { загальнооосвітньої } \\
\text { школи }\end{array}$ & $\begin{array}{c}\text { Дидактична } \\
\text { система вищої } \\
\text { школи }\end{array}$ \\
\hline
\end{tabular}

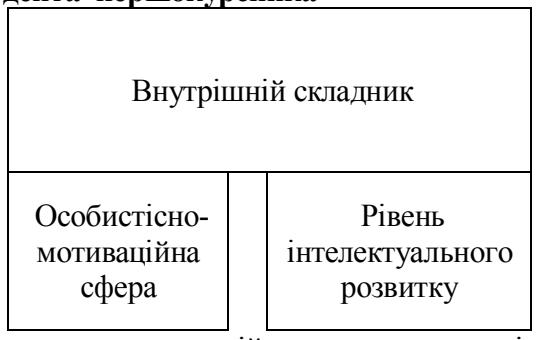

Насамперед, використання викладачами тих технологій навчання, котрі забезпечать поступовий перехід від шкільної системи до системи навчання у вищому навчальному закладі, які враховують наявний рівень мотивації навчання та навичок самостійної роботи. Також фактори, які охоплюють наявний рівень шкільної підготовки, спрямованість особистості, творчість мислення та стійке бажання оволодіти програмою вищої школи.

Задля реалізації принципу наступності в парадигмі учень старшої школи-студент вищого навчального закладу здійснення дидактичної адаптації форм, методів, прийомів і засобів самостійної пізнавальної діяльності відбувається ще й на основі усвідомлення того факту, що формат вступу до вищого навчального закладу відбувається через запровадження 32008 року зовнішнього незалежного оцінювання. Це вимагає від педагогічного процесу в старшій школі використання різних організаційних форм самостійної навчальної діяльності, приділення більшої уваги тестовим методикам, навичкам роботи з різними типами тестових завдань, зокрема із завданнями відкритої форми $з$ розгорнутою відповіддю. Навчальний процес у старшій школі повинен бути спрямований на оволодіння програмою старшої школи на рівні Державного стандарту повної загальної середньої освіти, максимально наближений до якісної підготовки випускника до зовнішнього незалежного оцінювання й успішної адаптації до навчання у вищому навчальному закладі.

Доцільним в організації навчально-виховного процесу у старшій школі вбачаємо застосування проблемного типу навчання, що активізує розумову діяльність учнів, спрямовану на задоволення пізнавального інтересу через отримання нової інформації.

На думку А. Кузьмінського, В. Омеляненка «пояснювально-ілюстративний тип навчання впродовж двох століть став переважаючим на всіх рівнях навчальної діяльності. Він певною мірою сприяв раціональному підходу до оволодіння значним обсягом усталених знань, розвитку логічного мислення та оперативної пам'яті. Проте 
загалом цей тип навчання стояв на заваді залучення учнів до активної самостійної пізнавальної діяльності і розвитку інтелектуальних можливостей кожної особистості, оволодіння методами самостійної пізнавальної діяльності» [1, с. 99-100].

Власний педагогічний досвід дає можливість стверджувати, що схарактеризовані форми роботи активізують пізнавальну активність старшокласників, передбачають самостійний пошук знань, роботу з різними джерелами інформації, власну творчість. Все це створює умови для інтенсивного розвитку інтелектуальних здібностей розуміння, рефлексії, конструктивного мислення (проектування, програмування, комунікації).

Отже, дидактична адаптація форм, методів, прийомів i засобів самостійної пізнавальної діяльності сприяє реалізації принципу наступності в парадигмі учень старшої школи - студент вищого навчального закладу. Цікавим є підхід до проблеми зв'язку форм навчання в загальноосвітньому навчальному закладі та вищому, що дозволяє поєднувати елементи дидактики середньої та вищої освіти. Така адаптація забезпечує формування стійкого інтересу до навчання, до самоосвіти та самовдосканалення, набуття необхідних практичних умінь і навичок для організації самостійної навчальної діяльності.

Перспективою подальших досліджень у цьому напрямку $є$ розроблення та апробування дидактичної моделі організації самостійної навчальної діяльності учнів старшої школи.

\section{Література}

1. Кузьмінський А. І. Педагогіка / А. І. Кузьмінський, В. Л. Омеляненко. - Київ : Знання, 2007. - 447 с. 2. Куписевич Ч. Основы общей дидактики / Ч. Куписевич. - М. : Высшая школа, 1986. - 320 с. 3. Ягупов В. В. Педагогіка: [навч. посіб.] / Василь Васильович Ягупов. - Київ : Либідь, 2003. - 560 с.

УДК 373.6:51

Олександр Сахновський

\section{НАВЧАННЯ «ЗА ПРОФІЛЕМ»: УКРАЇНСЬКА ШКІЛЬНА ОСВІТА В ПОШУКУ НОВОЇ МОДЕЛІ}

Сахновський О. С. Навчання «за профілем»: українська шкільна освіта в пошуку нової моделі.

Автор висвітлює актуальні питання впровадження профільного навчання в сучасній українській школі. Розкриваються пріоритетні напрямки його організації в умовах трансформації традиційного освітнього середовища. Відзначено, що профілізація $\epsilon$ структурною перебудовою, яка стосується сукупності важливих складників шкільного життя i, стимулюючи певні позитивні процеси в освіті, посідає своє місце в їі різнорівневій системі.

Ключові слова: профільне навчання, організація, школа, освіта, індивідуалізація, самовизначення, компетентність.

Сахновский А. Е. Обучение «по профилю»: украинское школьное образование в поисках новой модели.

Автор освящяет актуальные вопросы внедрения профильного обучения в современной украинской школе. Раскрываются приоритетные направления его организации в условиях трансформации традиционной образовательной среды. Отмечено, что профилизация представляет собой серьезную структурную перестройку, которая затрагивает целый комплекс важных составляющих школьной жизни и, 